\title{
The Drivers of Transnational Subsidiary Evolution: The Upgrading of Process R\&D in the Irish Pharmaceutical Industry
}

\author{
CHRIS VAN EGERAAT and PROINNSIAS BREATHNACH \\ Department of Geography \& National Institute for Regional and Spatial Analysis, National University of Ireland, Maynooth, \\ Kildare, Ireland.Emails: chris.vanegeraat@nuim.ie and Proinnsias.breathnach@nuim.ie
}

(Received July 2008: in revised form March 2011)

VAN EgeraAt C. and BREathnach P. The drivers of transnational subsidiary evolution: the upgrading of process R\&D in the Irish pharmaceutical industry, Regional Studies. This paper contributes to the theory of subsidiary evolution in large corporations through an examination of the driving forces behind upgrading of process research and development (R\&D) activities in the Irish pharmaceutical industry. Drawing on a survey of pharmaceutical plants and interviews with transnational pharmaceutical plants, it is shown that vigorous growth is occurring in the incidence of process $\mathrm{R} \& \mathrm{D}$. The paper supports the utility of a multilevel systems perspective on subsidiary evolution. The external environment, internal environment and subsidiary drivers are seen to drive upgrading in a systemic way. The primary drivers for the subsidiaries' enhanced role are located in the global external environment.

Transnational corporations Subsidiary evolution Research and development (R\&D) Pharmaceutical industry Ireland

VAN EgERAAT C. and BREATHNACH P. 跨国分支机构演化的驱动因素: 爱尔兰制药工业工艺研发的升级. 区域研究. 本 文通过分析爱尔兰制药工业的工艺研发活动背后的驱动因素，对大公司分支机构的演化理论做出贡献。基于对制药 厂的问卷调查以及与跨国制药厂的访谈，研究发现工艺研发活动的增长强劲。本文认为分支机构演化的多层次系统 观是有用的。外部环境、内部环境以及分支机构驱动力通过一种系统的方法来推动升级活动。分支机构地位强化的 主要驱动力来自全球外部环境。

\section{跨国公司分支机构演化 研发 制药工业 爱尔兰}

VAn Egeraat C. et Breathnach P. Les forces motrices de l'évolution des filiales transnationales: le renforcement de la R et D de procédés dans l'industrie pharmaceutique irlandaise, Regional Studies. Cet article contribue à la théorie de l'évolution des filiales des grandes sociétés à partir d'un examen des forces motrices qui sont à l'origine du renforcement des activités de recherche et développement ( $\mathrm{R}$ et $\mathrm{D}$ ) de procédés dans l'industrie pharmaceutique irlandaise. Puisant dans une enquête des établissements pharmaceutiques et des interviews auprès des établissements pharmaceutiques transnationaux, on montre que l'incidence de la $\mathrm{R}$ et $\mathrm{D}$ de procédés à tendance à s'accroître vigoureusement. L'article voit l'évolution des filiales sous un jour systématique à plusieurs niveaux. On considère que le milieu externe, le milieu interne et les forces motrices des filiales pilotent le renforcement d'une manière systémique. Les principales forces motrices nécessaires au rôle accru des filiales sont à trouver dans le mileu mondial externe.

Sociétés transnationales Évolution des filiales Recherche et Développement (R et D) Industrie pharmaceutique Irlande

Van Egeraat C. und Breathnach P. Die treibenden Kräfte der transnationalen subsidiären Evolution: Verbesserung der Erforschung und Entwicklung von Verfahren in der irischen Pharmabranche, Regional Studies. Dieser Artikel versteht sich als Beitrag zur Theorie der subsidiären Evolution in Großbetrieben durch eine Untersuchung der treibenden Kräfte hinter einer Verbesserung der Aktivitäten zur Erforschung und Entwicklung von Verfahren in der irischen Pharmabranche. Anhand einer Erhebung unter pharmazeutischen Betrieben und Interviews mit transnationalen pharmazeutischen Betrieben wird gezeigt, dass die Inzidenz der Verfahrenserforschung und -entwicklung von starkem Wachstum geprägt ist. Der Beitrag liefert Argumente für den Nutzen einer mehrschichtigen Systemperspektive der subsidiären Evolution. Die externe Umgebung, interne Umgebung und subsidiären Faktoren werden als treibende Kräfte für eine Verbesserung auf systemische Weise betrachtet. Die primären treibenden Kräfte für die verbesserte Rolle der Subsidiaritäten befinden sich in der globalen externen Umgebung.

Transnationale Konzerne Subsidiäre Evolution Forschung und Entwicklung (F\&E) Pharmaindustrie Irland

Van Egeraat C. y Breathnach P. Los factores de la evolución subsidiaria transnacional: mejora de la I + D de procesos en la industria farmacéutica irlandesa, Regional Studies. Con este artículo contribuimos a la teoría de la evolución subsidiaria en grandes 
sociedades a través de un examen de los factores que impulsan mejoras en las actividades de la investigación y el desarrollo (I + D) de procesos en la industria farmacéutica irlandesa. Basándonos en un estudio con plantas farmacéuticas y entrevistas con plantas farmacéuticas transnacionales, demostramos que está ocurriendo un fuerte crecimiento en la incidencia de la I $+\mathrm{D}$ de procesos. En este artículo ofrecemos argumentos acerca de la utilidad de una perspectiva de sistema de varios niveles en lo que respecta a la evolución subsidiaria. Consideramos que el entorno externo, el entorno interno y los factores subsidiarios estimulan las mejoras de modo sistémico. Los factores principales para el papel mejorado de las subsidiaridades se sitúan en el entorno externo global.

Corporaciones transnacionales Evolución subsidiaria Investigación y Desarrollo (I + D) Industria farmacéutica Irlanda

JEL classifications: L52, L65, O14, O32

\section{INTRODUCTION}

This paper contributes to the theory of subsidiary evolution within transnational corporations (TNCs), a major growth area in research relating to TNCs. In particular, the paper interrogates key elements of this theory through an empirical analysis of the driving forces behind recent upgrading of process research and development $(\mathrm{R} \& \mathrm{D})$ activities in the Irish pharmaceutical industry. By doing so, the paper addresses the need, identified by BIRKINSHAw and HOOD (1998), for empirical studies that can test the relevance of the increasing number of theoretical models of subsidiary evolution. The paper begins with a review of the recent literature relating to subsidiary evolution, paying particular attention to the multilevel systems framework for analysing subsidiary evolution proposed by TAVARES (2001). This is followed, successively, by an account of the structure and organization of the R\&D cycle within large pharmaceutical firms and a description of the traditional spatial configuration of this cycle. The next section examines the recent growth in process $\mathrm{R} \& \mathrm{D}$ activities in Irish pharmaceutical subsidiaries based on a comprehensive survey of these subsidiaries supplemented by detailed interviews with corporate personnel in the industry. The key drivers accounting for this growth are then identified and explored, utilizing Tavares's analytical framework. Finally, some conclusions are drawn from the foregoing analysis.

\section{THEORIZING SUBSIDIARY EVOLUTION IN TRANSNATIONAL COMPANIES}

A considerable literature has developed in recent years concerning the extent to which subsidiary plants of large TNCs have experienced upgrading and evolution (YOUNG et al., 1994; BIRKINSHAW and HOOD, 1998; Hood and Taggart, 1999; Tavares, 2001). Early models of TNC organizational structures saw technology and other capabilities being developed centrally and then transferred to subsidiaries whose main function was to supply individual national markets - what Pearce (1992) has termed 'multidomestic miniature replicas'. The high level of centralization of $\mathrm{R} \& \mathrm{D}$ in particular was a function of the 'spatial fix' relating to the historical development of facilities and procedures, the economies of scale associated with centralization, the agglomeration economies arising from embeddedness in rich technological milieux, efficiencies in terms of coordinating the research effort, and avoidance of technology leakages which would be more likely where R\&D was decentralized (EATON et al., 1994; PeArCe, 1999a). To the extent that R\&D functions were allocated to overseas subsidiaries at all, they were largely limited to technical support of manufacturing operations, adaptation of products to local markets and technical support for overseas customers (FLORIDA, 1997; RONSTADT, 1978).

However, from the 1970s on, TNC organizational structures underwent a profound process of change in terms of the functions performed by subsidiaries and the nature of their relationships with their head offices, other operating units within their parent firms and the local environments in which subsidiaries are located. This organizational restructuring can largely be seen as a response to the pressures and opportunities arising from changes in the nature of markets and the increasing pace of technological change. Key ingredients here were the globalization process (which both broadened markets and intensified competition), the shortening of product life cycles and the need for greater flexibility in all areas of corporate activity (DunNing, 1995; PeArCe, 1992, 1999a). The liberalization of trade facilitated the rationalization of the earlier multi-domestic system of replicated plants, some of which were closed and others allocated specialized functions in emerging global production systems (BIRKINSHAw and HOOD, 1998; Gereffi, 1995; Pearce, 1999b). This was accompanied by an increasing tendency among TNCs to establish or expand overseas $\mathrm{R} \& \mathrm{D}$ activities, driven to a considerable extent by the desire to access, and learn from, the technological milieux in which overseas competitors were themselves embedded.

Many overseas subsidiaries therefore acquired new functional mandates (basic research, product and process development) and associated organizational and technological capabilities which both allowed and required them to tap into local technology knowledge bases (Cantwell and Mudambi, 1998; Cantwell and Piscitello, 2005; Schmid and Schurig, 2003; ZANFEI, 2000). Thus, where previously the function of most overseas subsidiaries was to exploit competences 
initially developed in their home countries, new types of creative subsidiaries emerged whose main function was to augment home-based capabilities (CANTWELL and Mudambi, 1998; Kuemmerle, 1999). As a result, many overseas subsidiaries came to occupy strategically important roles, as centres of product/process development within corporate structures in which hierarchical layers were increasingly replaced by horizontal 'heterarchical' networks (HEDLUND, 1986).

In spatial terms, the dominant feature of the growth of high-performance TNC subsidiaries has been their concentration not only in countries with a strong record of technological innovation, but also in the localized high-technology agglomerations within these countries which tend to be the principal sources of such innovation (Birkinshaw and Hood, 1998; CAntwell and Piscitello, 2005; Kuemmerle, 1999). However, there is also some evidence of functional upgrading, including the establishment of R\&D functions, at overseas manufacturing sites located in more peripheral regions. Such regions commonly portray characteristics (low skill levels, lack of physical and scientific infrastructure, supplier networks and support institutions) not conducive to R\&D activity and indeed have frequently been the main casualties of the rationalization by TNCs of their international structures discussed above (AMIN and Tomaney, 1995; Dicken et al., 1994). However, there are circumstances where significant development of $\mathrm{R} \& \mathrm{D}$ functions, especially process $\mathrm{R} \& \mathrm{D}$ functions, in peripheral branch plants has occurred.

A range of factors or drivers may have been at play. TNCs sought to aspire to boost flexibility and the pace of technological innovation by incorporating $R \& D$ functions in overseas production plants: the resulting co-location of research and production activities can be conducive to a more efficient learning process (PEARCE, 1999a; ZANFEI, 2000). In addition, observers identify a growing tendency for subsidiary units themselves to acquire, or seek to acquire, a greater depth of functions (BIRKINSHAw and HoOd, 1998; Birkinshaw et al., 1998; PeARCE, 1999b). Another reason may lie in substantial investment in upgrading skill levels and scientific infrastructures by governments of certain peripheral regions (BIRKINSHAw and HOOD, 1998). Finally, the lower personnel and operating costs and government incentives (especially R\&D tax credits) available in many peripheral regions may have played a role as well (Birkinshaw and Hood, 1998, CANTwell and Mudambi, 1998; Duga and Studt, 2006.

PATTERSON and BROCK (2002) treat the considerable body of work that deals with the different factors and processes which shape subsidiary evolution and how these vary between subsidiaries, firms, sectors and regions and nationalities (see also BARTLETT and Ghoshal, 1989; Forsgren et al., 2000; PATterson and Brock, 2002; Frost et al., 2002; SCHMid and SCHURIG, 2003) as a distinct stream in the subsidiary management literature: the 'subsidiary evolution stream'. In this stream, the static concentration on subsidiary roles that characterized the, preceding, 'subsidiary role stream' (BARTLETT and GHOSHAL, 1986; WHITE and Poynter, 1984; D'Cruz, 1986) was replaced by the more dynamic development potential of subsidiaries in host countries and an understanding of the drivers and processes of subsidiary evolution. Authors in the subsidiary evolution stream tend to adopt a more heterarchical view of the transnational organization and accord a greater level autonomy to the subsidiary in the evolutionary process. Accordingly there tends to be a greater attention for subsidiary level factors, although different models of subsidiary evolution emphasize different factors depending on the perspective and context of the researchers (BROCK, 2000).

BIRKINSHAW and HOOD (1998) provided an influential model of subsidiary evolution, emphasizing three drivers: the parent company (decisions made by head office managers regarding the allocation of activities), subsidiary choice and host country environment (including support of the host government and inward investment agencies and the strategic importance of the country). Although the authors acknowledge that the three mechanisms interact to determine the subsidiaries role, this point is not specifically developed. Based on this model, PATTERSON and BROCK (2002) present a more elaborate model that more specifically includes the idea of interaction amongst the drivers. In addition, the model recognizes the role of the global (in addition to the host country) environment, although this is integrated in the head office determinant.

TAVARES $(2001,2002)$, again building on the framework of BIRKINSHAW and HOOD (1998), proposes an elaborate multilevel systems perspective on subsidiary evolution. Tavares's analytical framework is built around three sets of subsidiary evolution 'drivers': firstly, those emanating from within subsidiaries themselves (for example, a desire on the part of subsidiary managements to enhance the functions which they perform); secondly, those deriving from the 'internal' environment of the TNC of which the subsidiary is a component (for example, supports for, and blockages to, subsidiary development emanating from the parent firm and 'sister' subsidiaries); and, thirdly, those deriving from the 'external' environment (Fig. 1).

Tavares adds significant embellishments to the other models of subsidiary evolution. Tavares's analytical framework is particularly useful in terms of her treatment of the external environment. Firstly, unlike earlier analyses (such as BIRKINSHAw and HOOD, 1998) that tended to equate the subsidiary's external environment with the host country in which it is located, Tavares sees the external environment as operating at four different spatial scales: the regional (micro-region), the national (the host country), the supranational (macro-region) and the global. Tavares also highlights the role which institutions (for example, inward investment agencies) can play in influencing subsidiary evolution at all levels in 


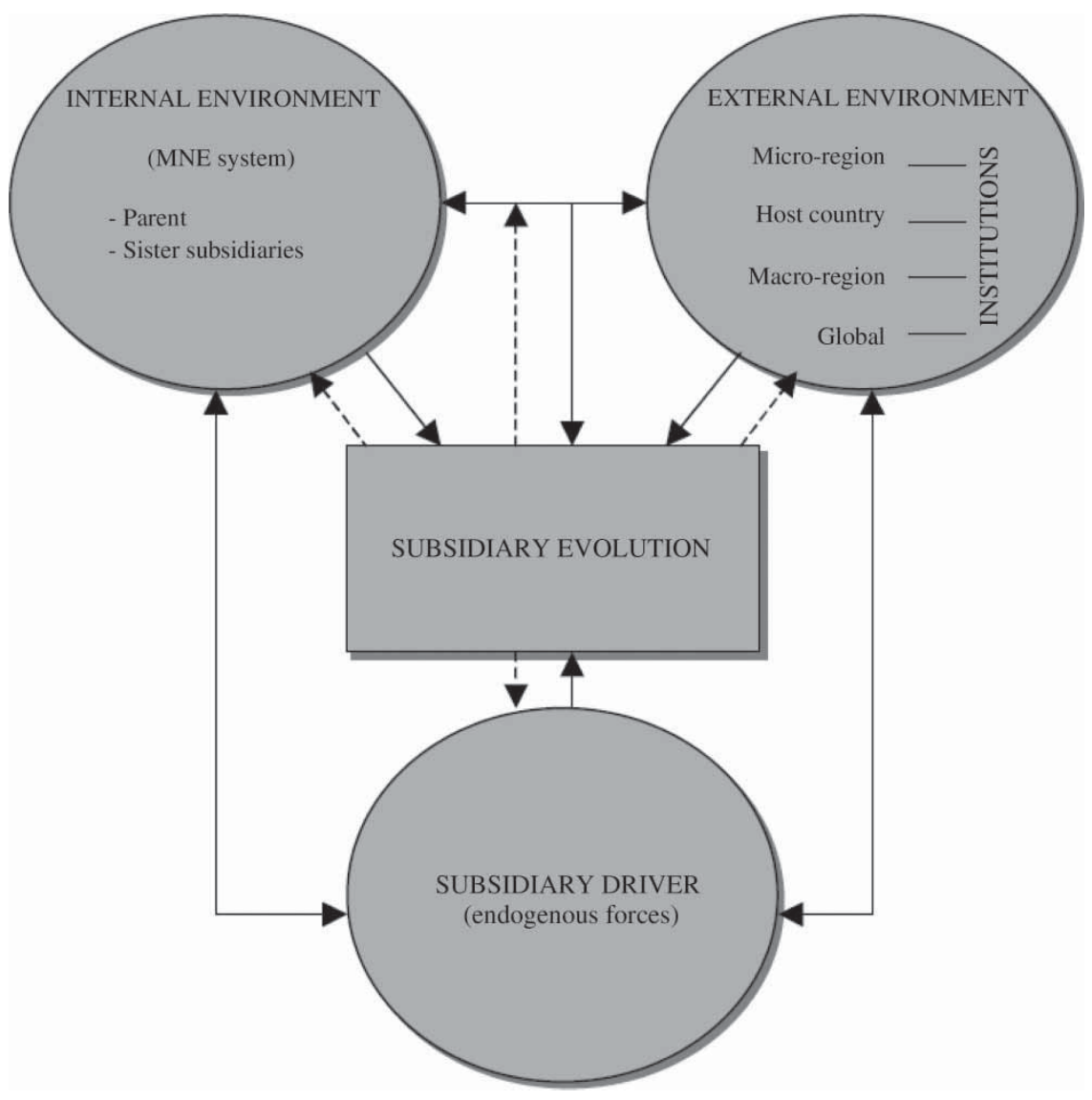

Fig. 1. Drivers of subsidiary evolution

Note: MNE, multinational enterprise. Source: TAVARES (2001)

this spatial hierarchy. The global external environment is recognized as a separate driver and not introduced as part of the head office driver (as in the case of PATTERSON and BROCK, 2002). Tavares, unlike BIR KINSHAw and HOOD (1998), also usefully incorporates non-territorial elements (for example, industrial competitive structure and technological change) into her conception of the external environment. Overall, according to Tavares, the external environment has impacted on the process of subsidiary evolution to a much greater extent than has been acknowledged in the existing literature. Tavares perceives a manifest need to give greater weight to environmental variables and argues that the most relevant influences need not be local.

A further key element in Tavares's analytical framework is its systemic approach which, more directly than BIRKINSHAW and HoOD (1998) and PATTERSON and BROCK (2002), addresses the complex fabric of linkages between distinct drivers. It provides for two-way 'dialectical' interactions between the various elements of the subsidiary evolution system, leading to evolution over time in the nature of these interactions. Not only do subsidiaries interact directly with both the internal (parent firm) and external (territorial and industrial) environments, but also the internal and external environments interact themselves in ways which can impinge indirectly on subsidiaries. This can give rise to very complex systems of interaction, the unpacking of which can be a daunting task.

This paper utilizes Tavares's framework to analyse the extent of, and drivers underpinning, the incorporation of process $\mathrm{R} \& \mathrm{D}$ activities into the subsidiaries of transnational pharmaceutical firms operating in Ireland. However, before addressing the findings, it next provides a description of the configuration of the R\&D cycle in the pharmaceutical industry, with particular reference to the role of process $\mathrm{R} \& \mathrm{D}$ in this overall cycle, followed by an account of the traditional spatial configuration of this cycle.

\section{THE RESEARCH AND DEVELOPMENT CYCLE OF THE PHARMACEUTICAL INDUSTRY ${ }^{1}$}

The pharmaceutical R\&D cycle includes both the development of new 'active ingredients' - also referred to as drug substances - and the development of related finished drug 'formulations' (the actual tablet, capsule or injection through which the active ingredient is delivered to patients). The R\&D cycle entails two distinct but strongly integrated sets of activities, that is 'product' and 'process' R\&D. ${ }^{2}$

The tasks of process R\&D are to develop an effective process for the large-scale manufacturing of a new drug product and to supply material for the clinical trial 
stages of the product R\&D cycle. The process R\&D cycle involves a number of integrated activities or stages (listed in Table 3). The cycle usually starts immediately after candidate selection with pre-formulation studies (where companies develop a deeper understanding of the candidate drug and explore alternative synthetic routes or processes). Promising routes or processes are then progressively evaluated and scaled up via 'paper experiments', computer simulation, small-scale laboratory experiments and experiments in the 'kilo lab' (a larger laboratory scale). Subsequently, the activities move to the pilot plant where the process is further scaled up with the research focus now on optimizing flow rates and equipment design. Apart from developing a manufacturing process, a second important function of the pilot plant is to produce material for larger-scale (Phase II and III) clinical trials.

The process R\&D cycle concludes with the transfer of drug production to commercial-scale plants which involves final equipment design, optimization in the commercial plant, validation, documentation of standard operating procedures and the training of operating staff. Process development continues during the entire life cycle of a drug in the form of continuous improvement activities conducted by technical staff at the commercial plant. This typically involves small, incremental, changes that do not require re-filing with the regulatory authorities. In addition, many companies will now start a new cycle of process R\&D for the same compound, generally referred to as 'second generation'. Such redevelopment activities, although requiring re-filing, tend not to involve a fundamental route change.

The various stages in the process $\mathrm{R} \& \mathrm{D}$ cycle require different numbers of researchers with different skill sets. Although all stages can involve skilled and highly educated staff, the early stages in the cycle involve the greatest number of, and the most highly skilled, researchers. Companies generally aim to have made most major decisions regarding the essential production process ('lock down' the process) in advance of the large-scale testing involved in Phase III clinical trials (activities 7 and 8 in Table 3). From here on, process development focuses on the final details of the process.

The various stages of the process R\&D cycle are strongly dependent on each other and on other functions in the pharmaceutical value chain. The initial stages of the process R\&D cycle, also referred to as process research (activities 1-4 in Table 3), are strongly integrated with each other as well as the discovery function in the product R\&D cycle. The pilot plant functions have backward links with the earlier process R\&D stages, forward links with manufacturing and parallel links with the clinical trials function in the product R\&D cycle. The post-pilot activities are all conducted at the commercial manufacturing plants and therefore tend to have strong links with manufacturing. This has an important influence on the spatial organization of process R\&D activity.
EARLY SPATIAL CONFIGURATION OF PROCESS RESEARCH AND DEVELOPMENT IN THE PHARMACEUTICALS INDUSTRY

The transnational pharmaceutical firms in the 1950s and 1960s were models of Fordist industrial organization. R\&D was typically organized as a linear process (Malecki, 1997; Hayter, 1998; Dicken, 2007). There existed a high degree of compartmentalization of specialized R\&D functions and of separation between R\&D and manufacturing. Planned interaction between departments was one-way and largely confined to the moments of transfer of finished tasks. The Fordist model involved a very distinctive geography of both R\&D and manufacturing production. The latter was generally located away from the headquarters regions and was frequently moved overseas, either to major markets (especially those protected by trade barriers) or to low-tax countries such as Ireland and Puerto Rico where profits could be concentrated via intra-corporate transfer price manipulation, a particularly important consideration for the highly profitable pharmaceutical industry (LALL, 1979). By contrast, until the 1980s, the R\&D functions of transnational pharmaceutical companies, particularly the more strategic activities, remained firmly located in their home countries, and usually in the same regions as the head offices and main production plants (Hayter, 1998, Howells, 1984). Some decentralization of R\&D did occur and branch plants frequently housed small technical/development units, but the scope of their activities was limited (Howells, 1984). Even in the case of process R\&D, typically, the manufacturing process was for the most part developed in the central R\&D laboratories with the technology then being transferred to the manufacturing division and manufacturing sites.

However, there are indications that this geographical configuration of process $\mathrm{R} \& \mathrm{D}$ is undergoing change (along the lines identified for transnational firms generally in the second section above), characterized by a decentralization of process $\mathrm{R} \& \mathrm{D}$ functions to the manufacturing subsidiaries of transnational pharmaceutical companies (CHIESA, 1996; Forfás, 2003; IRISH Council for SCIENCE TeChNology AND InNOVAtion (ICSTI), 2003; PISANO, 1997). This tendency is examined further in the following section, which focuses on the development of process $R \& D$ in the Irish pharmaceutical industry.

\section{PROCESS RESEARCH AND DEVELOPMENT IN THE IRISH PHARMACEUTICAL INDUSTRY}

This section examines the extent to which the suggested trend towards decentralization of process R\&D activities in the global networks of transnational pharmaceutical companies is apparent among the branch plants of transnational pharmaceutical firms located in Ireland. It 
begins with an account of the background and growth of the pharmaceutical industry in Ireland.

\section{Growth of the pharmaceutical industry in Ireland}

Foreign investment in the Irish pharmaceuticals industry commenced in the 1960s following the adoption by the Irish government of an inward investment promotion policy (based on the availability of tax incentives, capital grants and a plentiful supply of cheap labour) in the late 1950s (VAN EGERAAT and BREATHNACH, 2007; VAN EGERAAT, 2006). Inward investment in the industry accelerated in the 1970s, following Ireland's entry into the European Economic Community and the implementation by the Industrial Development Authority (IDA) of an aggressive marketing strategy which targeted the leading companies in emerging growth sectors, including pharmaceuticals (WHITE, 2000). This decade therefore saw a number of major investments, mainly by US firms, in the production of active ingredients and drug formulations (VAN EGERAAT and BARRY, 2009).

Following a brief period of stagnation in the early 1980 s, strong growth in the industry re-emerged in the second half of the decade and has continued more or less ever since, with employment rising from fewer than 5000 jobs in 1985 to 20200 in 2006 (VAN EGERAAT and BARRY, 2009). By far the strongest growth occurred in formulation, although the active ingredient subsector experienced significant expansion as well, particularly in the second half of the 1990s. In 2006, subsidiaries of foreign firms accounted for $96 \%$ of employment in the industry and $85 \%$ of plants. Foreign plants were, for the most part, relatively large scale (mean plant employment of 284) compared with the more modest scale of the indigenous sector (mean plant employment of seventy-six, with most below fifty). Indigenous companies were mainly active in the formulation of human and veterinary pharmaceuticals.

\section{Process RED activities in pharmaceutical firms in Ireland}

Data sources. The analysis that follows of Ireland's changing role in corporate process $\mathrm{R} \& \mathrm{D}$ in the pharmaceutical industry, and of the drivers underpinning this changing role, is based on data collected from two sources: a set of interviews at eleven transnational pharmaceutical companies and a mail survey of all sixty-eight foreign-owned pharmaceutical plants in Ireland engaged in the production of active ingredients and/or in drug formulation.

A total of fifty-three semi-structured, face-to-face, interviews were conducted with senior staff from eleven major transnational pharmaceutical plants in the period 2005-2006 (typically four to five interviews per plant). Interviewees included general managers, materials managers, personnel managers and process development managers. ${ }^{3}$ The selection process ensured that the sample included (large) companies in different subsectors (drug product and drug formulation), from different nationalities (five US, three UK, one Swiss, one French, one Japanese) and plants portraying different levels of involvement in process $\mathrm{R} \& \mathrm{D}$. The interviews focused on obtaining a detailed understanding of the global organization of process R\&D activities in the subject firms, the changing role of the Irish plants within these firms, as well as the processes and the drivers involved. The interview data form the basis of the discussion of the drivers of the evolution of process R\&D in the sixth section.

In addition, a mail survey was conducted of pharmaceutical plants in Ireland in 2006. The population of sixty-eight pharmaceutical plants ${ }^{4}$ was based on the annual Employment Survey of manufacturing plants in Ireland (2006 data) conducted by Forfás (the Irish government's National Policy and Advisory Board for Enterprise, Trade, Science, Technology and Innovation). The survey generated a response rate of $94 \%$ (sixty-four useable questionnaires), covering $91 \%$ of all employees in the target population in 2006. Table 1 presents the characteristics of the sixty-four respondent plants. The majority of plants are involved in drug formulation. The main countries of origin of the respondent plants included the United States, Germany, Britain and France (Table 2).

The main purpose of the mail survey was to quantify the process $\mathrm{R} \& \mathrm{D}$ activities in the Irish pharmaceutical industry and the relative role of the Irish subsidiaries in the global networks of their parent firms. To get an insight into this role, survey respondents were asked to rate the input of the local staff in various process $R \& D$

Table 1. Characteristics of survey respondent plants ${ }^{\mathrm{a}}$

\begin{tabular}{lrrc}
\hline & $\begin{array}{c}\text { Sample } \\
(n)\end{array}$ & $\begin{array}{c}\text { Population } \\
(N)\end{array}$ & $\begin{array}{c}\text { Percentage of } \\
\text { the population }\end{array}$ \\
\hline $\begin{array}{l}\text { Number of plants } \\
\text { Employment in plants }\end{array}$ & 64 & 68 & 94 \\
Plant type & & & 91 \\
Active ingredients & 25 & No data & \\
Drug formulation & 34 & No data & \\
Both active ingredients and & 5 & No data & \\
$\quad$ drug formulations & & & \\
\hline
\end{tabular}

Note: ${ }^{a}$ Employment numbers and percentages are based on Forfás employment survey data, 2006.

Table 2. Mail survey respondent plants by country of origin

\begin{tabular}{lc}
\hline Country of origin & Number of respondent plants \\
\hline United States & 32 \\
Germany & 7 \\
Britain & 6 \\
Japan & 6 \\
France & 5 \\
Switzerland & 2 \\
Italy & 2 \\
Other & 4 \\
Total & 64 \\
\hline
\end{tabular}


Table 3. Involvement of Irish plants in process research and development (RED) activities

\begin{tabular}{|c|c|c|c|c|c|c|c|c|c|}
\hline \multirow[b]{2}{*}{ Activity } & \multirow[b]{2}{*}{ Process $\mathrm{R} \& \mathrm{D}$ activities } & \multicolumn{8}{|c|}{ Likert-scale score (percentage of plants) ${ }^{a}$} \\
\hline & & 1 & 2 & 3 & 4 & 5 & 6 & 7 & Mean \\
\hline 1 & Pre-formulation studies & 74.6 & 6.8 & 0.0 & 1.7 & 5.1 & 3.4 & 8.5 & 2.0 \\
\hline 2 & Derivation of the initial route/process options and preliminary evaluation & 71.0 & 11.3 & 1.6 & 3.2 & 6.5 & 1.6 & 4.8 & 1.9 \\
\hline 3 & Evaluation in small-scale experiments & 63.9 & 13.1 & 3.3 & 3.3 & 4.9 & 1.6 & 9.8 & 2.2 \\
\hline 4 & Evaluation in the kilo lab & 62.1 & 10.3 & 5.2 & 1.7 & 5.2 & 6.9 & 8.6 & 2.3 \\
\hline 5 & Production for Phase II clinical trials & 52.8 & 13.2 & 5.7 & 5.7 & 7.5 & 1.9 & 13.2 & 2.6 \\
\hline 6 & Evaluation in the pilot plant prior to Phase III clinical trials & 39.6 & 17.0 & 17.0 & 7.5 & 5.7 & 5.7 & 7.5 & 2.7 \\
\hline 7 & Production for Phase III clinical trials & 25.9 & 5.6 & 9.3 & 9.3 & 14.8 & 16.7 & 18.5 & 4.1 \\
\hline 8 & Evaluation in the pilot plant during Phase III clinical trials & 27.8 & 9.3 & 14.8 & 7.4 & 16.7 & 13.0 & 11.1 & 3.6 \\
\hline 9 & Equipment design & 9.7 & 9.7 & 11.3 & 14.5 & 19.4 & 19.4 & 16.1 & 4.5 \\
\hline 10 & Optimization in a commercial plant (pre-filing) & 4.8 & 3.2 & 3.2 & 6.5 & 16.1 & 21.0 & 45.2 & 5.7 \\
\hline 11 & Validation & 0.0 & 0.0 & 3.2 & 4.8 & 6.5 & 22.6 & 62.9 & 6.4 \\
\hline 12 & Continuous improvement & 0.0 & 1.6 & 0.0 & 1.6 & 9.7 & 21.0 & 66.1 & 6.5 \\
\hline 13 & Development of a second-generation process & 9.8 & 8.2 & 14.8 & 4.9 & 14.8 & 11.5 & 36.1 & 4.9 \\
\hline
\end{tabular}

Note: ${ }^{a} 1$, No input in activity by the Irish plant; 7, Irish plant has sole ownership of activity.

activities of the parent firm on a seven-point Likert scale. The various categories are listed in Table 3 (for further detail, see the fifth section). The questionnaire used in the mail survey was, in most cases, completed by the head of the process development unit or technical services unit of the plants.

The scale and scope of process RED among survey firms. The mail survey found that in 2006 the surveyed firms employed a total of 739 staff in process R\&D. While some of these were part of a dedicated process $R \& D$ unit, most were employed in other functions such as production, technical support, and quality control, and devoted only part of their work time to process R\&D activities. Respondents were asked to estimate the proportion of their time that the people involved spent on process $\mathrm{R} \& \mathrm{D}$ activities. Based on this information it is estimated that process $\mathrm{R} \& \mathrm{D}$ employed the equivalent of 536 full-time people. However, the number of staff involved varied considerably between plants: twenty plants employed fewer than five, twenty-nine between five and fourteen, eight between fifteen and twenty-nine, while five plants employed thirty or more.

There had been very rapid recent growth in the number of $\mathrm{R} \& \mathrm{D}$ personnel. In the six-year period between 2000 and 2006, the number of people involved in process $\mathrm{R} \& \mathrm{D}$ in the responding companies grew by more than $140 \%$, from 306 to 739 . This compares with a $36 \%$ growth rate in total employment in the companies in the same period. Four-fifths of responding plants expanded their process R\&D staff in this period. As for the future, twenty-six of the respondent plants had concrete plans to expand their process R\&D activities in Ireland over the next five years. Out of these, twenty-three provided an estimate of the additional process $\mathrm{R} \& \mathrm{D}$ staff requirements over this period, amounting to a total of 291 additional staff.

In order to gauge the relative role of these subsidiaries in the overall process R\&D activities of their parent firms, respondents to the mail survey were asked to rate the input of the local staff in various process $\mathrm{R} \& \mathrm{D}$ activities of the parent firm on a seven-point Likert scale (where a score of 1 indicated that the Irish plant had no input in the activity; and a score of 7 indicated that the Irish plant had sole ownership of the activity in question). This key question only applied to the multi-site transnational firms. In addition, not all of the categories of R\&D activity included in the question applied to all these plants. As a result, the individual activity categories in the question applied to different numbers of foreign plants, ranging from fifty-eight to sixty-two. The responses are presented in Table 3, where the activity categories are listed in descending order in terms of their position in the process R\&D cycle sequence. In Table 3, the columns represent the proportion of relevant plants falling into each Likertscale score category while the 'Mean' column indicates the mean score obtained for all respondent plants for the relevant $\mathrm{R} \& \mathrm{D}$ activity.

The results show that the great majority of plants (with a small number of exceptions) have little or no involvement in the early stages of the process R\&D cycle (activities 1-4 in Table 3). Involvement rises somewhat for activities 5 and 6 (production for Phase II clinical trials and pilot plant evaluation and optimization prior to Phase III clinical trials) but still remains generally low. The involvement of the Irish plants only becomes substantial at Phase III clinical trials but the mean score for the involvement in production (activity 7) is higher than for involvement in evaluation and optimization (activity 8). This pattern suggests (and the interviews confirm) that in a substantial number of cases the main function of the staff involved in process development in Irish pilot plants is the manufacture of material to support clinical trials. The technology staff in the plants are generally involved in process $\mathrm{R} \& \mathrm{D}$ as members of global project teams made up of staff from the R\&D and manufacturing divisions of the parent firms drawn from different locations around the world. Such teams are normally set up at an early stage of the process 
R\&D cycle to facilitate early involvement in the cycle of all the relevant functions, including manufacturing, and to streamline the transition between the various stages and locations. A large part of the evaluation/optimization is carried out by staff from the process $\mathrm{R} \& \mathrm{D}$ groups in the core global research locations, both at these core locations and/or at the site in Ireland. In many cases, staff from the Irish units, as members of the global project teams, have some involvement in evaluation/optimization, even if not involved in the production of the evaluation batches. However, in most cases the involvement is very limited, particularly at the early stages.

There is a very significant upward shift in the level of Irish plant participation in the technology transfer phase of the process R\&D cycle - optimization in the commercial plant (activity 10) and the running of validation batches (activity 11). Technology transfer essentially involves taking a process from the pilot plant scale and replicating it with, preferably, minor changes at the commercial manufacturing plant. This activity is typically organized through commissioning teams that include staff from the transferring location and, on the receiving end, local staff with responsibility for new product introductions. Once the commercial manufacturing plant is up and running, continuous improvement activities (activity 12) tend to be carried out almost entirely by local staff. At this stage staff from the core research locations tend to have a very limited, more consultative, role.

Overall the mail survey data clearly show that the involvement of the Irish staff in process $\mathrm{R} \& \mathrm{D}$ only becomes substantial after the proof-of-concept point, at the start of Phase III clinical trials. As pointed out in the outline of the process R\&D cycles, this is the point at which companies generally want to have locked down the process parameters. From here on process R\&D activities focus on the final details of the process and technology transfer.

The fact that the Irish plants tend to concentrate their involvement in process $\mathrm{R} \& \mathrm{D}$ activities in the later stages of the cycle does not mean that they are involved in low-skill activities. The mail survey shows that the process R\&D activities employ a substantial number of highly skilled people, with $30 \%$ of the 739 people involved holding a doctorate as their highest level of academic attainment, with $18 \%$ having a master's degree, and a further $46 \%$ a primary degree.

Having outlined the specific nature of the process R\&D activities which have recently been decentralized to the Irish operations, the paper now turns to an analysis of the factors that have driven this tendency to decentralize.

\section{THE DRIVERS OF THE EVOLUTION IN PROCESS DEVELOPMENT ACTIVITIES IN IRISH PHARMACEUTICAL SUBSIDIARIES}

In analysing the drivers of process $\mathrm{R} \& \mathrm{D}$ decentralization, this section employs the analytical framework proposed by TAVARES (2001) which distinguishes between drivers operating in the external environment, those operating in the internal environment (that is within the parent corporation), and those emanating from within the Irish subsidiaries themselves, while at the same time emphasizing the fact that the different drivers act in a systemic way, involving processes of mutual interaction, reinforcement and co-evolution. The following subsections are organized so as to highlight the interactions between drivers. Most of the described interactions involve the external environment. Tavares sees external drivers as operating at four spatial scales: the global, the (supranational) macro-regional, the national (host country), and the (sub-national) micro-regional. Given the relatively small size of Ireland, the micro-regional scale was deemed to be of limited significance for the evolution of process R\&D activities and is not integrated in the analysis.

Changes in the global competitive and technological environment leading to a focus on efficiency in process RED (global external environment-internal environment interaction)

Since the 1980s pharmaceutical companies have been increasingly confronted by major, global, changes in their competitive, regulatory and technological environments. Many of these changes had an impact on the corporate strategy (internal environment), including on the way companies organized and spatially configured the process development function.

The combination of increasingly stringent regulatory requirements, the concomitant reduction of the effective period in which a product enjoys patent protection (Howells et al., 2005; PisANO, 1997), greater complexity of new product and process technologies (PISANO, 1997), higher levels of competition due to the emergence on new biotechnology firms and the introduction of price controls by governments (AGRAWAL, 1999) has substantially increased the costs and reduced the revenues of pharmaceutical companies.

These developments in their external environment spurred pharmaceutical companies to review their corporate strategies and organizational configurations. A key target of this review process has been the inefficiencies in the Fordist organization of R\&D and production. The compartmentalization of specialized R\&D functions, the separation between R\&D and manufacturing, and the one-way interaction between departments involved a lot of wastage, high costs and long development times (HAYTER, 1998).

The review resulted in widespread restructuring of the way the TNCs configure their global process $\mathrm{R} \& \mathrm{D}$ operations. This reorganization is designed to reduce not only the cost of developing and manufacturing new products, but also, more importantly, the time it takes to bring new products to the market, thereby increasing the effective patent protection period (PisAnO, 1997). One of the key themes in the 
reorganization of process $\mathrm{R} \& \mathrm{D}$ is 'coordination integration', involving better integration between both the various stages of the process $R \& D$ cycle and the product discovery, process development and manufacturing functions.

This increase in the degree of coordination integration and the concomitant requirement for improved communication flows can explain, at least in part, the rise in the level of process development activities in Irish pharmaceutical manufacturing subsidiaries in recent years. PISANO (1997) suggests that coordination between process R\&D and manufacturing is best facilitated through the co-location of these functions, which previously tended to be separated. However, the idea of co-location of process $\mathrm{R} \& \mathrm{D}$ and manufacturing is complicated by the fact that transnational firms generally operate multiple manufacturing plants around the world. In this context co-location can lead to fragmentation of the process $\mathrm{R} \& \mathrm{D}$ function, and the impairment of information flow within the overall corporate R\&D organization (MALECKI, 1997). Location decisions regarding (individual) process development functions relative to other functions necessarily involve a tradeoff between these conflicting considerations.

This trade-off is reflected in the organization and spatial configuration of the process development activities of the surveyed companies. The interviews all confirmed a strong emphasis on coordination between the process development and manufacturing functions. Process development project teams involve members from various organizations, including discovery, process R\&D and commercial manufacturing. The coordination involves a large amount of information exchange, including face-to-face exchange. In relation to the pilot plants, the interviewees generally confirmed that co-location with the commercial manufacturing plants in Ireland did facilitate information exchange, particularly when technology was being transferred to the latter plants. At the same time, invariably, the early-stage process $\mathrm{R} \& \mathrm{D}$ functions remain strongly centralized in the core global research locations, partly to facilitate communication with the centralized discovery groups and partly to achieve economies of scale. In fact, a large part of the actual process $R \& D$ work in the Irish pilot plants is carried out by staff from central process development groups. Strongly developed organizational links and advanced information and communication technology infrastructure between the core process development locations and the staff at the pilot plants reduces the requirement for travel to an extent. As one pilot plant manager mentioned:

We have learned that telecommunications are extremely effective. Once you establish a relationship face-to-face, you can maintain that very effectively. [...] We don't even use the video anymore. Telephone is fine. We use the video system for data display. We find that to be hugely valuable. We can edit documents on line

(Manager of an active ingredient pilot plant, 2006)
Still, centrally located staff need to travel regularly to carry out the process development and technology transfer work in conjunction with staff based at the local facilities. Hence, at least some of the gain in efficiency in face-to-face information exchange between the pilot plant and the commercial plant comes at the expense of a higher amount of travel between the pilot plant in Ireland and the process development groups in the core locations.

Co-locating pilot plants at commercial plants in Ireland streamlines the technology transfer to the commercial plant in other important ways as well. Firstly, it can significantly speed up the regulatory process in that, in order to register a production process, batches produced at the pilot plant need to be inspected by the regulatory authorities. If this pilot plant is located at the same site as the commercial plant, registration of the process will qualify the entire site, including the commercial plant. This significantly shortens the length of the overall registration process. Finally, co-location of the pilot and commercial plants also facilitates post-launch continuous improvement and process redevelopment (second-generation) activities. Typically, a large part of these activities is carried out by the manufacturing organization and its staff located at the commercial plants. Since their work can require experimentation in the pilot plants, co-location provides obvious efficiencies.

To quantify the relative importance of possible reasons for locating process $\mathrm{R} \& \mathrm{D}$ activities in Ireland, the respondents at subsidiaries with process development units were asked to rate a set of possible reasons on a five-point Likert scale. Six key reasons were identified (Table 4). The desire to have process $R \& D$ located near the manufacturing plant to support the efficiency of the process development trajectory was clearly the most important factor (with an average score of 4.3). This was followed, in descending order of importance, by: the efforts of the government to increase the value added of the local operations; the desire of local management to increase the profile of the operations; the relative availability of skilled labour; the desire to tap in the local skills base; and the lower cost of skilled labour in Ireland. The interviewees were in most cases not in a position to score the role of the international taxation regime. These reasons will be discussed in the following sections.

Global competitive environment and market liberalization leading to consolidation of plants (global and supranational external environment-internal environment interaction)

Changes in the global competitive and technological external environment also stimulated process development activities by changing the relative size of the Irish manufacturing operations. This was driven by two factors. The first of these was a wave of merger and acquisition activity which occurred in the global pharmaceutical industry in the 1990s - itself a response 
Table 4. Reasons for locating a process development unit in Ireland ${ }^{\mathrm{a}}$

\begin{tabular}{lc}
\hline & $\begin{array}{c}\text { Mean Likert-scale } \\
\text { score }^{\mathrm{b}}\end{array}$ \\
\hline $\begin{array}{l}\text { Desire to have process research and develop- } \\
\text { ment located near manufacturing plant }\end{array}$ & 4.3 \\
Desire to tap into local skills base (quality) & 2.9 \\
Lower cost of skilled labour & 1.8 \\
Relative availability of skilled labour & 2.9 \\
$\begin{array}{l}\text { Desire of local management/staff to increase the } \\
\text { profile of the operations }\end{array}$ & 3.0 \\
Efforts of the Irish government to increase the & 3.2 \\
$\quad$ value added of the local operations & \\
\hline
\end{tabular}

Notes: ${ }^{a}$ Interviewees were in many cases not in a position to score the role of the international tax regime.

${ }^{\mathrm{b}}$ Mean score on a five-point Likert scale: 1 , factor played no role; 5 , factor played a crucial role.

to the growing global competitive pressures being experienced in the industry at the time (AGRAWAL, 1999). A common consequence of these mergers and acquisitions was the rationalization of excess manufacturing capacity (SCHOfIELD, 2001). Secondly, the Single European Market and the ongoing World Trade Organisation negotiations have greatly reduced the necessity to operate duplicate drug product plants in different national markets, as had previously been the norm in the pharmaceutical industry (SCHWEITZER, 1997; GAMBARDELLA et al., 2000). A number of companies responded to this change in their external environment by rationalizing their manufacturing plants on a European or even global scale. Both dynamics have lead to a concentration of manufacturing capacity in fewer and larger plants or 'super-manufacturing' facilities (ICSTI, 1999).

For reasons mainly related to its (long-) established corporate taxation regime, Ireland was an attractive location for the consolidated facilities which emerged from this rationalization process, with the result that many pharmaceutical subsidiaries in Ireland became the largest manufacturing sites in their corporate networks (VAN EGERAAT and BARRY, 2009). An increasing number of these plants now act as 'strategic sites' responsible for global new product launches. As a result, the Irish sites became prime targets for the relocation of process development activity arising from the new organizational structures described above. To give an example, one of the respondent plants was established in the early 1990 s to consolidate the formulation activities of thirteen existing European manufacturing plants. At the time of the interview a new pilot plant had been added to the site and a substantial process development unit had been established, employing forty-five staff and a further expansion of this group, involving a further forty staff, had been announced.

Again the initial impetus for subsidiary evolution originated in the general changes in the external operating environment but was channelled through the internal environment of the parent company to the benefitting subsidiaries.

Changes in the taxation regime leading to corporate decisions to locate pilot plants in Ireland (global external environment-internal environment interaction)

A third instance of change in the external environment which has operated through the internal corporate environment to stimulate the location of process $\mathrm{R} \& \mathrm{D}$ in the Irish subsidiaries is related to the (international) tax regime within which pharmaceutical TNCs operate. At first glance, Ireland's low corporation tax should work against TNCs carrying out R\&D activities in Ireland, as TNCs generally prefer to undertake R\&D in high-tax regimes so that R\&D expenditure can be written off against higher rates of corporation tax, thereby reducing the global tax bill (ICSTI, 1999, 2003). The attraction of the United States as a location for $\mathrm{R} \& \mathrm{D}$ is further enhanced by relatively generous tax allowances for R\&D expenses.

However, interviews with staff at international accountancy firms and material from existing studies (MutTi and Grubert, 2007) suggest that developments in other aspects of international and national taxation regimes, notably those related to intellectual property (IP), have actively encouraged the location of process R\&D in Ireland.

The key event in this respect was the introduction, in the mid-1990s, of US legislation for Cost-Sharing Arrangements (CSAs) which permits companies in different jurisdictions to share the R\&D costs involved in developing IP. Because the costs are shared, the revenues and profits arising from the development of IP may also be shared. This provides an instrument which allows TNCs to shift some profits to subsidiaries (registered as separate companies) in jurisdictions (such as Ireland) where corporation tax rates are lower than in the United States, thereby facilitating a significant reduction in the global effective tax rate for the TNC in question.

Typically a CSA involves a buy-in payment where the Irish subsidiary pays the parent company for the value of the pre-existing IP. In theory this buy-in payment should be a fair reflection of the value of the IP transferred. However, the system is susceptible to abuse and pharmaceutical firms are widely believed to undervalue the buy-in payments. This is supported by the creation of complex global administrative structures and the location of functions additional to manufacturing, including $\mathrm{R} \& \mathrm{D}$, in low-tax jurisdictions such as Ireland. The presence of such R\&D facilities can be used to justify inflated levels of IP, value added and profits attributed to the Irish subsidiaries. A common justification device is the involvement of Irish subsidiaries in the development of second generations of existing products (see also MUtTi and GRUBERT, 2007; Simpson, 2005; The Irish Times, 2006). 
These developments illustrate the systemic nature of the processes and the co-evolution of the drivers involved in subsidiary evolution. On the one hand, these developments can be interpreted as 'the multinational shifting governance modes and structures in response to environmental shocks' (TAVARES, 2001, p. 146). On the other hand, the environmental shock was, to an extent, the outcome of lobbying on the part of the TNCs.

This research was unable to quantify the relative importance of the international tax regime because interviewees at local subsidiary level were in many cases not in a position to score the role of this regime. But the comments of the vice-president of one of the respondent companies, located at the global headquarters, were revealing. After discussing the details of the international taxation regime and its influence on the location of the pilot plant in Ireland, he summarized the situation as follows:

the synergies are the main drivers, but the other driver is tax advantages. [...] So there is synergies, there is the regulatory issue and there is tax.

To the interviewer's question which factor weighed strongest, the answer was unambiguous: 'Tax.'

In reaction to the changes in the global external and internal environments, host country policies enhance the attractiveness of Ireland (global external-internal-national-external interactions)

The majority of plans for the establishment or major expansions of process $\mathrm{R} \& \mathrm{D}$ units originated in the 'internal environment' (mainly instigated by changes in the global competitive and technological environment and in the international taxation environment). To what extent have developments in the national external environment (the host country) played a role or influenced these plans and related location decisions, and how do these developments interact with other drivers?

Ireland's technological system in the area of pharmaceuticals has not been particularly attractive to TNCs investing in $\mathrm{R} \& \mathrm{D}$ units. However, in recent years, partly in reaction to the new opportunities offered by the increasing internationalization of $\mathrm{R} \& \mathrm{D}$ functions by TNCs, the Irish government implemented a range of measures to upgrade the local factor conditions and stimulate value-adding activities in the pharmaceutical industry.

The supply of science and technology graduates and high-level science researchers grew rapidly in the 1990s, partly due to increased government investment in education. Between 1993 and 2004, the annual output of science and technology graduates from the higher education system grew by $50 \%$ (calculated from data given in DUFF, 2007). The research infrastructure received a further boost through a substantial increase in funding of research institutions and research projects. Finally, several tax-relief and grant measures have been introduced with the specific objective of promoting $\mathrm{R} \& \mathrm{D}$ and innovation in foreign-owned branch plants.

A large share of the new resources has been used to support the pharmaceutical/biotechnology sector, which has been identified as possessing considerable potential for future growth. For example, Science Foundation Ireland (SFI), in its first three years of operation, allocated $40 \%$ of its $€ 550$ million basic research fund to research in biosciences and bioengineering (SFI, 2006). Cognisant of the above-mentioned changes in the global 'external' and corporate 'internal' environments, Irish industrial policy documents specifically promoted process $\mathrm{R} \& \mathrm{D}$ as an important area for higher value-added activity (ICSTI, 2003; ENTER PRISE Strategy Group, 2004). In line with this, in 2006 the technology infrastructure for pharmaceutical process $\mathrm{R} \& \mathrm{D}$ was significantly expanded with the establishment of the government-funded National Institute for Bioprocessing Research and Training - a centre of excellence for the Irish bioprocessing industry.

In relation to the availability of skilled workers, the Likert-scale scores (Table 4) suggest that the relative availability of skilled labour and the increased quality of the research skills of graduates in the Irish labour pool has exerted a limited positive influence on the decisions to locate process development units in Ireland (a mean score of 2.9 on a five-point Likert scale). However, evidence from the actual discussions suggests that the attraction lies in the availability rather than in the quality of the graduates and that the really high-end skills remain in short supply.

Relative availability was probably a big driver and it still probably is relative to other countries. I think the biggest challenge is that we need to get the right skills coming forward. And I don't think the academic institutions necessarily understand what the right skills are. [...] I think the process engineering in Ireland historically has been about going out and working in a manufacturing plant. We are not developing process engineers with $\mathrm{PhDs}$ and with fundamental scientific focus. [...] The universities are very oldfashioned, with test tubes. They are behind the times you know. [...] Coming out of Ireland the $\mathrm{PhDs}$ tend to be too narrow. They are not broad enough.

(Director of an active ingredient pilot plant, firm 10, 2006)

We don't have an oversupply of suitable employees. So when we recruited for the unit, day one we brought in a lot of people from France and the UK. [...] So really, because there is so little R\&D in Ireland to start with, we were not able to poach it of people. [...] I think there is not enough of a focus in [the education system of Ireland. It is engineering, and the tech transfer and the running of the process. We are looking here at a lot more creative synthetic chemistry, quite a big emphasis on learning. So we are finding it a bit of a challenge [to find staff with suitable skills].

(Manager of a process development centre, firm 5, 2006)

This suggests that, in relation to education and skills, the Irish national environment is trailing the growing 
requirements of pharmaceutical subsidiaries located in Ireland. This in turn suggests that, although the expansion and upgrading of the skills pool has served to enhance Ireland's attractiveness as a base for process $\mathrm{R} \& \mathrm{D}$ functions, and has facilitated the greater role of subsidiaries in process $\mathrm{R} \& \mathrm{D}$, the instigating drivers for the greater involvement of Irish subsidiaries in process $\mathrm{R} \& \mathrm{D}$ reside primarily in the global and macro-regional external environment and the related corporate response (internal environment).

As regards the upgrading of the pharmaceutical research infrastructure, this upgrading is of relatively recent origin and certainly played no role in relation to the process development units which were established during the 1990s. However, two interviewees suggested that it positively influenced recent investments in process development activity.

Finally, Table 4 shows that other efforts by the Irish government to increase the value added of the local operations of foreign pharmaceutical plants played a positive role as well, receiving an average score of 3.2. Interviewees typically mentioned the grants supplied by the industrial development agencies and, often in the same breath, the supporting role of the IDA in general. Nearly all process R\&D projects had received government funding. Several interviewees also corroborated AMIN and TOMANEY's (1995) very positive assessment of the role played by the IDA, which often had a direct involvement in the development of grant applications.

Subsidiary management proposes process $R E D$ projects to corporate headquarters (internal environment-subsidiary interaction)

The subsidiary evolution literature tends to give much attention to subsidiary-level factors (PATTERSON and BROCK, 2002) and these factors are generally seen as the main driver. In support of TAVARES (2001), this clearly was not the case in the context of the Irish pharmaceutical industry. The highly regulated nature of process development in the pharmaceutical industry strongly restricts the room for autonomous development of initiatives by 'entrepreneurial' local subsidiary management. This is not to say that the local subsidiaries play no role in driving their own evolutionary process. The company interviews identified a small number of projects that started on the initiative of the Irish subsidiary. In these cases the projects depended strongly on the quality and energy of local staff. One interviewee even gave evidence of the need to overcome structural inertia' at the parent company level (TAVARES, 2001).

It took quite a while to convince people [to establish the local pilot plant]. The biggest barrier was that we already had a pilot plant in our organization. So why build a new one in Ireland.

(Director of an active ingredient pilot plant, firm 10, 2006)

In addition to a desire to improve the efficiency of the process development trajectory and plant performance through the attraction of a process $\mathrm{R} \& \mathrm{D}$ function, the interviews suggest that local subsidiary management is also driven, in some cases, by motives linked to intersubsidiary competition and personal career advancement. The desire of local management/staff to enhance the profile of the Irish subsidiary within the corporation received a mean score of 3.0 on the five-point Likert scale. Such enhancement is deemed important for the long-term survival of the subsidiary in the face of corporate consolidation activities and rising factor costs in Ireland. Local technology staff are also driven by the desire to be involved in more advanced and challenging activities. One manager of a technology group in a plant with a limited process development remit put it as follows:

We have highly educated skilled professionals working in the department and all we want is a crack at it. It can be a bit frustrating.

(Manager of a process technology group, drug product plant, firm 8, 2006)

These examples illustrate that the local subsidiary driver does interact and influence the internal (corporate) environment and that this played some role in the evolution of the pharmaceutical subsidiaries. Nevertheless, it is clear from the interviews that the main impetus behind the majority of establishments or major expansions of process R\&D units in the survey firms originated from within the internal environment (the parent), mainly driven, in turn, by developments in the global external environment. The first quote also pertinently illustrates how the evolution of the local subsidiary can be influenced by the activities of sister subsidiaries.

\section{CONCLUSIONS}

This paper has found that vigorous growth is occurring in the incidence of process R\&D activity among manufacturing subsidiaries of transnational pharmaceutical firms located in Ireland. While this activity is concentrated in the less skill-intensive later stages in the process $\mathrm{R} \& \mathrm{D}$ cycle, it has nevertheless involved a substantial upgrading in skill levels in the plants concerned.

In examining the drivers responsible for this evolution, the analytical framework proposed by TAVARES (2001) proved to be fruitful. The model's embellishments to other models for subsidiary evolution (BIRKINSHAW and Hood, 1998; Patterson and Brock, 2002) are pertinent. Almost all the categories and subcategories of drivers identified by Tavares were found to be influential in the Irish case, with Irish subsidiary upgrading arising from a combination of impulses deriving from the external environment, the internal corporate environment of the parent firms of Irish subsidiaries, and the subsidiaries themselves. Furthermore, the external drivers were seen to operate at different spatial scales, as proposed by Tavares, including the global/industrial (new regulatory, 
technological and competitive contexts), the macroregional (in the form of rationalization processes resulting from the creation of the Single European Market) and the host-country (Irish government measures to stimulate industrial development in general and functional upgrading in particular) levels. The findings show that the primary drivers for the subsidiaries' enhanced role in process $\mathrm{R} \& \mathrm{D}$ lie in the external environment, notably at the global/industrial level. This supports Tavares's contention that greater weight needs to be given to environmental drivers of subsidiary evolution and that the most relevant influences need not be local. If supported by future studies, this finding calls for a softening of the focus on local factors which dominates the current regional studies literature.

A particularly insightful element of Tavares's framework for subsidiary evolution - its systemic nature, whereby various drivers mutually interact, co-evolve and operate through each other to influence subsidiary evolution - was seen to work to particular effect in the Irish case. For example, the changes in the internal organization of $\mathrm{R} \& \mathrm{D}$ within pharmaceutical firms which favoured the transfer of process R\&D functions to Irish subsidiaries were themselves driven by the need on the part of these firms to respond to key developments in their global/industrial external environments. At the same time, some of the changes in the external environment were partly influenced by actions in the internal environment, as in the case of the introduction of US legislation for cost-sharing arrangements and the Irish governments' efforts to upgrade the local factor conditions.

Ultimately, the significant upgrading that has occurred in the process $\mathrm{R} \& \mathrm{D}$ functionality of Irish pharmaceutical subsidiaries has arisen largely from developments in the global external environment which have proved serendipitous for Ireland; initiatives undertaken by the Irish government and the Irish subsidiaries themselves have only been of secondary significance in this context. This points to the contingent nature and inherent fragility of the Irish industrial structure, dominated as it is by subsidiary operations of transnational firms.

The findings highlight opportunities and challenges for Ireland in its pursuit of process R\&D functions in the pharmaceutical industry. On the one hand there is great opportunity for the expansion of activities in the final stages of the process R\&D cycle either through the establishment of new process $\mathrm{R} \& \mathrm{D}$ units or in the form of expansion of staff numbers at existing units. The findings suggest that this, in itself, requires further efforts to expand and upgrade the national pool of workers with relevant process development skills. On the other hand, serious challenges remain in relation to the upstream phases of the process $\mathrm{R} \& \mathrm{D}$ cycle. In the short-term the Irish government's latitude to stimulate these upstream phases is limited. Corporations will prove very reluctant to move such activities away from their core product R\&D units and it is questionable whether such upstream process R\&D activities can be developed in Ireland without the parallel development of a product R\&D infrastructure. This will not prove an easy task given the fact that the product $R \& D$ functions of transnational companies are becoming increasingly concentrated in a small number of global innovation 'megacentres' and, as yet, Ireland is not close to joining this league (VAN EGERAAT and BARRY, 2009).

Acknowledgements - The research for this paper was supported by a grant from the Irish Research Council for the Humanities and Social Sciences. The authors would like to thank Barry O'Leary of IDA Ireland for facilitating this research; and three anonymous referees for their constructive comments.

\section{NOTES}

1. The R\&D cycle of the pharmaceutical industry is very complex. This section confines itself to presenting a concise overview of this cycle, and to highlighting certain aspects of the cycle which are particularly germane to the empirical part of the paper and the associated arguments regarding the drivers of subsidiary evolution. For a more detailed description of the pharmaceutical R\&D cycle, see VAN EgERAat (2010). This section is partly based on PISANO (1997) supplemented with information obtained during company interviews.

2. The product $\mathrm{R} \& \mathrm{D}$ cycle can be divided into four stages: initial drug discovery, preclinical development, clinical development and regulatory approval. The discovery stage is concerned with research into the causes of diseases and the identification of compounds that could be active in relation to the treatment of certain diseases. Compounds that offer most potential (drug candidates) are then tested on animals in the preclinical development stage, with any candidate which emerges successfully from this stage entering the clinical development stage, during which the drug is tested on humans. This stage generally involves three phases, during which the drug is tested on increasingly large groups of human subjects. Successful Phase II trials can lead to the drug candidate achieving what is termed 'proof of concept' status, which sanctions the commencement of the costly Phase III trials, where the drug is tested on thousands of patients.

3. In addition to these interviews at subsidiary level, two interviews were conducted at the global headquarters of two of the respondent firms as well as with staff at the Industrial Development Agency, The Irish PharmaChemical Association and two international accountancy firms with specialist knowledge of the industry.

4. By 'plant' the authors refer to single plant operations as well as to sites with multiple plants, but operating as one subsidiary or branch. 


\section{REFERENCES}

Agrawal M. (1999) Global Competitiveness in the Pharmaceutical Industry: The Effect of National Regulatory, Economic and Market Factors. Pharmaceutical Products Press, New York, NY.

Amin A. and Tomaney J. (1995) The regional development potential of inward investment in the less favoured regions of the European Community, in Amin A. and Tomaney J. (Eds) Behind the Myth of European Union: Prospects for Cohesion, pp. 201220. Routledge, London.

Bartlett C. and Ghoshal S. (1986) Tap your subsidiaries for global reach, Harvard Business Review 64(6), 84-87.

Bartlett C. A. and Ghoshal S. (1989) Managing across Borders: The Transnational Solution. Harvard Business School Press, Cambridge, MA.

BIRKINSHAw J. and Hood N. (1998) Multinational subsidiary evolution: capability and charter change in foreign-owned subsidiary companies, Academy of Management Review 23(4), 773-795.

Birkinshaw J., Hood N. and Jonsson S. (1998) Building firm-specific advantages in multinational corporations: the role of subsidiary initiative, Strategic Management Journal 19, 221-241.

Brock D. (2000) Review of multinational corporate evolution and subsidiary development by Birkinshaw and Hood, Academy of Management Review 24(1), 259-261.

Cantwell J. and Piscitello L. (2005) Recent location of foreign-owned research and development activities by large multinational corporations in European regions: the role of spillovers and externalities, Regional Studies 39(1), 1-16.

Cantwell J. and Mudambi R. (1998) The Location of MNE RED Activity: The Role of Investment Incentives. Discussion Papers in International Investment and Management Series B 250. Department of Economics, University of Reading, Reading.

ChIESA V. (1996) Separating research from development: evidence from the pharmaceutical industry, European Management Journal 14(6), 638-647.

D'Cruz J. (1986) Strategic management of subsidiaries, in Etemad H. and Dulude S. (Eds) Managing the Multinational Subsidiary, pp. 75-89. Croom Helm, London.

Dicken P. (2007) Global Shift: Mapping the Changing Contours of the World Economy. Sage, London.

Dicken P., Forsgren M. and Malmberg A. (1994) The local embeddedness of transnational corporations, in Amin A. and Thrift N. (Eds) Globalisation, Institutions and Regional Development in Europe, pp. 23-45. Oxford University Press, Oxford.

Duff C. (2007) Ireland's Economic Progress. The Taxpayers Network, Green Bay, WI (available at: http://www.taxpayersnetwork. org) (accessed on 1 December 2010).

Duga J. and Studt T. (2006) Global R\&D report, RED Magazine September, 1-17.

Dunning J. H. (1995) Re-appraising the eclectic paradigm in an age of alliance capitalism, Journal of International Business Studies 6(3), 461-491.

Eaton B., Lipsey R. and Safarian A. (1994) The theory of multinational plant location: agglomerations and disagglomerations, in EDEn L. (Ed.) Multinationals in North America, pp. 79-102. University of Calgary Press, Calgary, AB.

Enterprise Strategy Group (2004) Ahead of the Curve: Ireland's Place in the Global Economy. Forfás, Dublin.

FLORIDA R. (1997) The globalization of R\&D: results of a survey of foreign-affiliated R\&D laboratories in the USA, Research Policy 26, 85-103.

FORfás (2003) The Supply and Demand for Skills in the Biotechnology Industry. Forfás, Dublin.

Forsgren M., Johanson J. and Sharma D. (2000) Development of MNC centres of excellence, in Holm U. and Pedersen T. (Eds) The Emergence and Impact of MNC Centres of Excellence: A Subsidiary Perspective. Macmillan, Houndsmills.

Frost T., Birkinshaw J. and Ensign P. (2002) Centers of excellence in multinational corporations, Strategic Management Journal 23(11), 997-1018.

Gambardella A., Orsenigo L. and Pammolli F. (2000) Global Competitiveness in Pharmaceuticals: A European Perspective. Enterprise Directorate-General of the European Commission, Brussels.

Gereffi G. (1995) Global production systems and Third World development, in Staldings B. (Ed.) Global Change, Regional Response: The New International Context of Development, pp. 100-142. Cambridge University Press, Cambridge.

Hayter R. (1998) Research and development, in Daniels P. and Lever W. (Eds) The Global Economy in Transition, pp. 64-190. Longman, Harlow.

Hedlund G. (1986) The hypermodern MNC: a heterarchy, Human Resource Management 25(Spring), 9-35.

Hood N. and Taggart J. (1999) Subsidiary development in German and Japanese manufacturing subsidiaries in the British Isles, Regional Studies 33, 513-528.

Howells J. (1984) The Location of research and development: some observations and evidence from Britain, Regional Studies 18(1), 13-29.

Howells J., Gagliardi D. and Malik K. (2005) Strategic sourcing for innovation: organisational and locational issues in the pharmaceuticals sector. Paper presented to workshop on 'Organisational Configurations and Locational Choices of Firms: Responses to Globalisation in Different Industry and Institutional Environments', University of Cambridge, Cambridge, UK, 14-15 April 2005.

Irish Council for Science Technology and Innovation (ICSTI) (1999) Technology Foresight Ireland. ICSTI, Dublin.

Irish Council for Science Technology and Innovation (ICSTI) (2003) Embedding the Pharmachem Industry in Ireland. ICSTI, Dublin.

KUEMMERLE W. (1999) The drivers of foreign direct investment into research and development: an empirical investigation, Journal of International Business Studies 30, 1-24. 
LALl S. (1979) Multinational companies and concentration: the case of the pharmaceutical industry, Social Scientist 7(8/9), 3-29.

Malecki E. (1997) Technology E Economic Development: The Dynamics of Local, Regional and National Competitiveness. Addison Wesley Longman, Harlow.

Mutti J. and Grubert H. (2007) The Effect of Taxes on Royalties and the Migration of Intangible Assets Abroad. Working Paper Number W13248. National Bureau of Economic Research (NBER), Cambridge, MA.

Patterson S. and Brock D. (2002) The development of subsidiary-management research and theoretical analysis, International Business Review 11, 139-163.

Pearce R. (1992) Factors Influencing the internationalization of research and development in multinational enterprises, in Buckley P. and Casson M. (Eds) Multinational Enterprises in the World Economy, pp. 75-95. Edward Elgar, Aldershot.

Pearce R. (1999b) The evolution of technology in multinational enterprises: the role of creative subsidiaries, International Business Review 8, 125-148.

PeArCe R. D. (1999a) Decentralised R\&D and strategic competitiveness: globalised approaches to generation and use of technology in multinational enterprises, Research Policy 28, 157-178.

Pisano G. (1997) The Development Factory: Unlocking the Potential of Process Innovation. Harvard Business School Press, Boston, MA.

Ronstadt R. (1978) International R\&D: the establishment and evolution of research and development abroad by seven US multinationals, Journal of International Business Studies 9, 7-24.

Schmid S. and Schurig A. (2003) The development of critical capabilities in foreign subsidiaries: disentangling the role of the subsidiary's business network, International Business Review 12, 755-782.

SChofield M. (2001) The global pharmaceutical industry, in KIRKBride P. (Ed.) Globalisation: The External Pressures, pp. $251-284$. Wiley, New York, NY.

Schweitzer S. (1997) Pharmaceutical Economics and Policy. Oxford University Press, New York, NY.

Science Foundation Ireland (SFI) (2006) Annual Report and Accounts 2005. SFI, Dublin.

Simpson G. (2005) Wearing of the Green: Irish subsidiary lets Microsoft slash taxes in U.S. and Europe, Wall Street Journal 7 November.

Tavares A. (2001) Strategic Management of Multinational Networks: A Subsidiary Evolution Perspective. Discussion Papers in International Investment and Management. University of Reading, Reading.

TAVAres A. (2002) Multinational subsidiary evolution and public policy: two tales from the European periphery, Journal of Industry, Competition and Trade 2(3), 195-213.

The Irish Times (2006) GlaxoSmithKline pays \$3.1bn in tax settlement, The Irish Times 12 September.

Van Egeraat C. (2006) The Pharmaceutical Industry in Ireland: Agglomeration, Localisation, or Simply Spatial Concentration. Working Paper Number 28. National Institute for Regional and Spatial Analysis (NIRSA). National University of Ireland, Maynooth.

Van Egeraat C. (2010) The scale and scope of process R\&D in the Irish pharmaceutical industry, Irish Geography 43(1), 35-58.

VAn EgeraAt C. and Barry F. (2009) The Irish pharmaceutical industry over the boom period and beyond, Irish Geography 42(1), 23-44.

Van Egeraat C. and Breathnach P. (2007) The manufacturing sector, in Kitchin R. and Bartley B. (Eds) Understanding Contemporary Ireland, pp. 125-146. Pluto, Dublin.

White R. and Poynter T. (1984) Strategies for foreign-owned subsidiaries in Canada, Business Quarterly 48(4), 59-69.

White P. (2000) The muscles of the Celtic tiger: IDA's winning sectors', in Mac Sharry R. and White P. (Eds) The Making of the Celtic Tiger, pp. 272-308. Mercier, Cork.

Young S., Hood N. and Peters E. (1994) Multinational enterprises and regional economic development, Regional Studies 28, $657-677$.

ZANFeI A. (2000) Transnational firms and the changing organisation of innovative activities, Cambridge Journal of Economics 24, $515-542$. 